\title{
Laboratory Evaluation of the Toxicity of Silver Nanoparticles Against Housefly, Musca Domestica (Diptera: Muscidae)
}

\author{
Madiha M. Abd El-Hamid ${ }^{1}$, Eglal M. Helal ${ }^{1}$ and Fadwa T. Mohamadeen ${ }^{1}$
}

\begin{abstract}
The synthesis of nanomaterials is currently one of the most active in nanoscience branches; especially those help improve the human quality life. Silver nanoparticles (AgNPs) are an example of this as it is known to have inhibitory and bactericidal effects and as one of the famous metal nanomaterials in broad Sectors especially in agriculture. It was synthesized by a chemical method and characterized by UV-visible spectroscopy, TEM, and SEM in this present study. The nanoparticles were ranged between 20-50 $\mathrm{nm}$ and the shape seem grain with rough ends. The larvicidal activity of silver nanoparticles AgNPs were tested against the third instar larvae of housefly, $M$. domestica. Six concentrations were used over two different application methods (Dipping and Feeding methods) under laboratory conditions. In general, it was noticed that the larvicidal effects based on $\mathrm{LC}_{50}$ of either method against the housefly. The LC $\mathrm{C}_{50}$ value for AgNPs was $45.5 \mathrm{mg} / \mathrm{ml}$ by feeding method in a different concentration $(60,40,32,24,16,8 \mu \mathrm{g} / \mathrm{ml})$. Data showed the moderate effect in larval mortality $\%$ and high effect of inhibition of pupation \% and inhibition of adult emergence\%. Furthermore, the treatment caused some morphological effects such; abnormalities of larvae and pupae, larval pupal intermediates, deformed adult with crumpled wings. Also, some adults couldn't emerge and remained in their puparia.
\end{abstract}

Key words: Musca domestica, Chemical Synthesis, SEM, TEM, UV-VIS Spectroscopy Silver Nanoparticles, larvicidal activity.

\section{INTRODUCTION}

The housefly, M. domestica has spread all over the world as a commensal of humans and share them in activities. It is the most common fly species found in houses. Typhoid, cholera, bacillary dysentery, tuberculosis, and infantile diarrhea are some of the common diseases transmitted by housefly (Fotedar 2001; Malik et al., 2007 and Pavela 2008). Although housefly species does not bite, its populations can irritate people and animals by flying around and landing on them or on their food and leave regurgitation and fecal spots on the surface (Hinkle 2002; Steenberg and Jespersen 2002 and Winpisinger et al., 2005) in general the housefly control is based on the use of chemical insecticides like organophosphates, organochlorines, and pyrethroids. However, spend a lot of chemical insecticides is increase the deterioration of the environment, also leads to the development of resistance among insects (Srinivasan, et al., 2008; Kamaraj, et al., 2011). In addition, considering the biohabitat of housefly insecticides favorable or at least compatible to human surroundings are needed which is not possible with chemical insecticides.

In search of environmentally friendly and effective pesticides, nanoparticles could be a new and good strategy for this reason. Nanoparticles, generally considered as particles with a size range between 1$100 \mathrm{~nm}$, display completely new or improved properties as compared to the large particles of bulk materials that they are composed of based on specific characteristics such as size, distribution, and morphology (Wildenberg, 2005). Studies on nanoparticles and their effects on insect pest are not widely known (Chinnamuthu and Murugesa-Boopathi 2009). In 2012, Khot, et al., mentioned that nanotechnology has emerged as a promising area for developing and utilizing nanosized particles with a wide range of use, including pesticides applications. When transformed into nanoparticles, materials including phytochemicals acquired novel properties where they offer large specific surface area, thermal stability, biodegradability and increased affinity to the target and, hence, penetrate rapidly and selectivity accumulated within the living cells enhancing various activities (Bordes et al., 2009; Margulis-Goshen and Magdassi 2013). Silver nanoparticles (AgNPs) have been used in many medical, pharmaceutical and agricultural applications as a pure free metal or in a compound forms because it possesses a wide array of biological activities such as insecticidal and antimicrobial activities. They are nontoxic to humans (Yeo et al., 2003). There is a number of approaches are available for the synthesis of silver nanoparticles such as thermal decomposition (Navaladian et al., 2007), electrochemical (Starowicz et al., 2006), microwave assisted process (Sreeram et al., 2008), mechanical milling (Arbain etal., 2011) and green chemistry methods (Begum et al., 2009). Therefore, the present work has been devoted to evaluate the silver nanoparticles (AgNPs) as an insecticidal agent against larvae and pupae of housefly through feeding toxicity

\footnotetext{
${ }^{1}$ Department of Applied Entomology, Faculty of Agriculture, Alexandria University, Egypt,

Corresponding Author: fadwa.mohamadyn@gmail.com

Received September 05, 2018, Accepted September 30, 2018
} 
and dipping methods. Thereafter the first method was traced down to the full emergence of adult.

\section{MATERIALS AND METHODS}

\section{1- Synthesis of Silver Nanoparticles (Ag-NPs):}

The material and technique were made in the practical workshop in Nakaa Nanotechnology Network NNN in Cairo the whole method was according to (Rashid et al., 2013). The TSC is the method of Synthesis Ag nanoparticles using tri sodium citrate as a reducing agent. Starting materials for the preparation of silver nanoparticles were trisodium citrate silver nitrate. The silver colloid was prepared by using chemical reduction method. The reacting materials (all solutions) were prepared in distilled water. In an exemplary experiment, $50 \mathrm{ml}$ of $0.001 \mathrm{M} \mathrm{AgNO}_{3}$ was heated to boil. Then added $5 \mathrm{ml}$ of $1 \%$ trisodium citrate to previous solution drop by drop. Through the process, solutions were mixed vigorously and heated until the change of color was (pale yellow). At this point stop heating and stirred until cooled to room temperature. The mechanism of reaction could be expressed as the follows: $4 \mathrm{Ag}^{+}+\mathrm{C}_{6} \mathrm{H}_{5} \mathrm{O}_{7} \mathrm{Na}_{3}+2 \mathrm{H}_{2} \mathrm{O} \rightarrow 4 \mathrm{AgO}+$ $\mathrm{C}_{6} \mathrm{H}_{5} \mathrm{O}_{7} \mathrm{H}_{3}+3 \mathrm{Na}^{+}+\mathrm{H}^{+}+\mathrm{O}_{2} \uparrow$ The characterization of silver nanoparticles was done by using UV-Visible spectroscopy, SEM and TEM.

\section{2- Characterization of Ag NPs:}

a) UV-Visible spectroscopy:

A small amount of AgNPs sample was diluted in distilled water. This sample was further subjected to spectral analysis. Ag reduction was monitored by observing UV-Vis spectrum between the range of 300 $\mathrm{nm}$ - $600 \mathrm{~nm}$. UV-Vis spectroscopy is generally recognized to examine size and shape of nanoparticles.

\section{b) Electron Microscopy Analysis:}

Morphological characterization and particles size of the AgNPs was done by transmission electron microscopy (TEM) and scanning electron microscopy (SEM) analysis.

\section{c) For the TEM analysis:}

The Ag colloidal solution was filtered by frequent centrifugation and be allowed to sonication; a drop of this solution was applied to make a thin layer on the copper-coated grid and let it dry, and analyzed using TEM (JEM-1400 plus)

\section{d) For the SEM analysis:}

The preparation of samples by dropping nanoparticle suspension onto aluminum stubs and let them dry by air. The dried particles were coated with gold up to a thickness of $400 \mathrm{~A}$ in a sputter- coating units (JFC-1100 E). Observation of silver nanoparticles (AgNPs) in the coadted specimens were performed in a Jeol JSM-5300.
Scanning electron microscope operated between 15 and $20 \mathrm{KeV}$.

\section{3- Housefly, Musca domestica, rearing:}

The initial housefly population was established at Applied Entomology Lab. from pupae provided by the Institute of Medical Insect Research, Cairo, Egypt. The emerged adults were reared in entomological cage $(30 \times$ $30 \times 30 \mathrm{~cm})$ at $26 \pm 2{ }^{\circ} \mathrm{C}$ under 12:12 light/dark and $70 \% \mathrm{RH}$. Adult flies were provided with $2.5 \%$ sugar solution and fed on mixture of 9: 9: 2: 1.5: $1(\mathrm{v} / \mathrm{v})$ of sugar, skim milk powder, autolyzed yeast powder, egg yolk powder and cholesterol (Singh and Jerram 1976). Eggs being laid were transferred to another artificial diet of larvae prepared from whole milk powder $(100 \mathrm{~g})$, dried brewer's yeast $(25 \mathrm{~g})$, agar $(30 \mathrm{~g})$, methyl phydroxybenzoate $(0.3 \mathrm{~g})$, streptomycin sulphate $(100 \mathrm{mg})$ water to $1000 \mathrm{ml}$. According to Singh and Jerram (1976) with some modification.

\section{4- Laboratory Bioassay:}

\section{a) Larval Mortality:}

The larval bioassay was evaluated using two methods, feeding method (mixed with food media) and dipping methods:

\section{b) Dipping Methods:}

The larval bioassay was evaluated using a dipping method according to (Sinthusiri and Soonwera 2010). Fifteen of the third instar larvae were dipped into $10 \mathrm{~mL}$ of each tested concentrations for $30 \mathrm{sec}$ and then transferred to a filter paper (in a plastic cup). Six concentrations with 3 replicates were prepared, while control larvae were dipped in distilled water for $30 \mathrm{sec}$. larval mortality was recorded by larval wasting and immobility after $24 \mathrm{~h}$ the of treatment. The lethal concentration $\left(\mathrm{LC}_{50}\right)$ were calculated, the test included a set control group (distilled water).

\section{c) Feeding Method:}

Larvicidal activity of synthesized AgNPs was evaluated according to Wright (1971) as standard methods. Larvicidal tests were based by exposing $M$. domestica third instar larvae to food contaminated with tested materials. Based on the wide range, AgNPs was tested at $8,16,32,24,40,60 \mu \mathrm{g} / \mathrm{ml}$ concentrations. Fifteen third instar larvae were put in a plastic cup containing $20 \mathrm{ml}$ of artificial diet, and $1 \mathrm{ml}$ of silver nanoparticles was added. For each concentration, three replicates were used, for a total of 45 larvae. The larval mortality was recorded at $24 \mathrm{~h}$ after exposure. The test included a set control group (distilled water). The lethal concentration $\left(\mathrm{LC}_{50}\right)$ were calculated. 


\section{d) Pupicidal Activity:}

The pupal bioassay was evaluated as the following of the (feeding method) mixed food media technique we traced the treated larvae until the pupal stage. In addition, we were recorded the pupl weight of highest, lowest concentration and control in initial (at the first day of pupation) to compare them with the others which recorded at the end of pupal period (after 5 days). The abnormalities were saved as a photographic. Also, we recorded the percentage of inhibition rate (PIR) and the inhibition rate of adult emergence (IR\%).

$$
\% \mathrm{IR}=\mathrm{Cn}-\mathrm{Tn} / \mathrm{Cn} \times 100
$$

Where $\mathrm{Cn}$ is the number of newly emerged insect in the untreated (control) and Tn is the number of insects in the treated.

\section{5- Statistical analysis:}

The obtained data was tabulated in MS Excel and average mortality was calculated among three replicates. The average mortality was converted into Corrected \% mortality using Abbott's formula (Abbott,1925). Probit analysis was performed to calculate $\mathrm{LC}_{50}$ values using SPSS software. The values for probit equations (y), coefficient chi-squared test $\left(x^{2}\right)$, lethal concentration $50 \%\left(\mathrm{LC}_{50}\right)$, and $95 \%$ Lower and Upper Confidence limit (LCL-UCL) were obtained for test concentrations after $24 \mathrm{~h}$. Also, mean percent larval mortality data were subjected to analysis of variance and compared with One Way analysis of variance (ANOVA), Finney (1971).

\section{RESULTS}

\section{Characterization of Ag NPs:}

Color change was noted by visual observation synthesized AgNPs, the color changed to light yellow (pale yellow). During the reaction and later, it changed to light brown by the time and after that no significant change occurred (figure $1 \mathrm{a}, \mathrm{b}$ ). The most widely technique was used for structural characterization of silver nanoparticles is UV-Visible spectroscopy. It is highly sensitive to the existence of silver colloids because these nanoparticles exhibit an intensive absorption peak due to the excitement of plasmon surface. The absorption band in the $350 \mathrm{~nm}$ to $450 \mathrm{~nm}$ region is typical for the silver nanoparticles. With increasing particles size, the plasmon absorption shifts toward red Figure (2). The scanning electron microscopy images at different magnifications of the synthesized AgNPs nanoparticles are shown in Figure (3).

\section{Larvicidal bioassays:}

\section{a) Dipping methods:}

Larvicidal effect: the present results in the Table (1) show the result of AgNPs on the mortality of the third instar larvae of house fly (M. domestica) after dipping it in the varying concentrations. The mortality percentage was ranged between (2-33\%) in lowest and highest concentrations respectively. The mortality rate was less than $50 \%$ which is not considered as a significant result $(\mathrm{F}=12.759 \mathrm{p} \leq 0.05 \mathrm{Sig}=0.00)$ but when we tried estimate the $\mathrm{LC}_{50}$ by probit analysis program, it was $63.8 \mu \mathrm{g} / \mathrm{ml}$ with confidence limits between (52.3-87.9 $\mu \mathrm{g} / \mathrm{ml}$ ) and the relationship was a liner relation with formal $\mathrm{y}=1.43-0.03 * \mathrm{x}$.

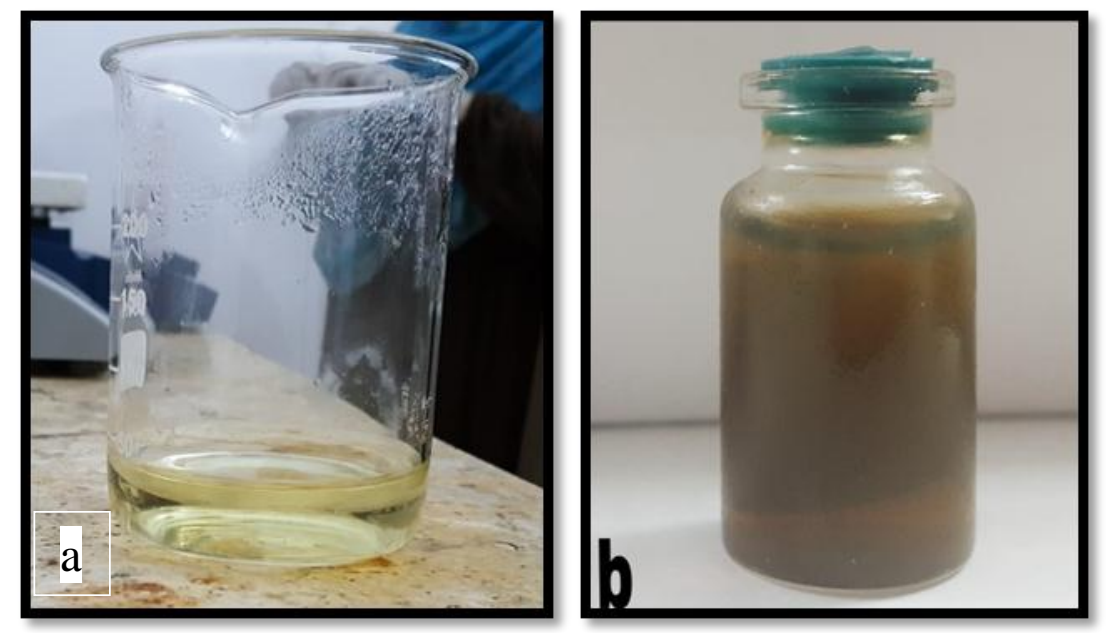

Figure 1. Changes of color that occurs to indicate the end of reaction. 


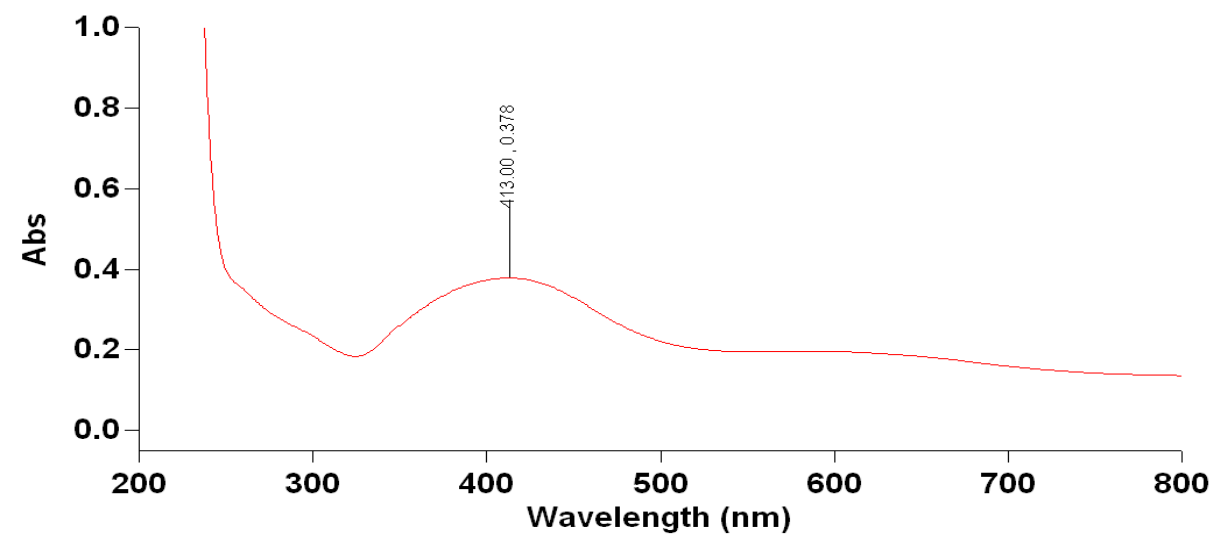

Figure 2. UV-vis spectra of aqueous solution of synthesized silver nanoparticles AgNPs

(A)

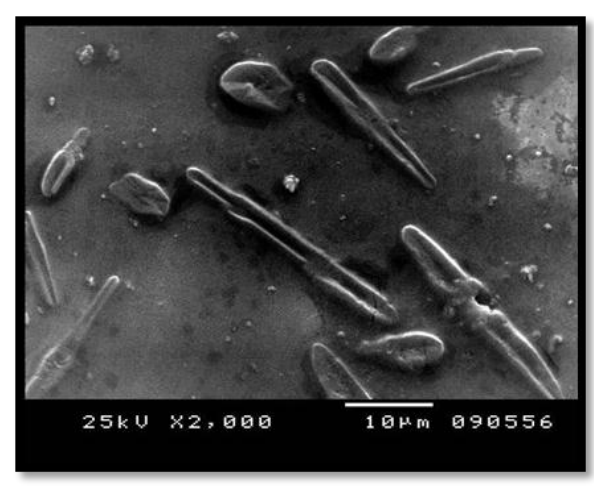

(C)
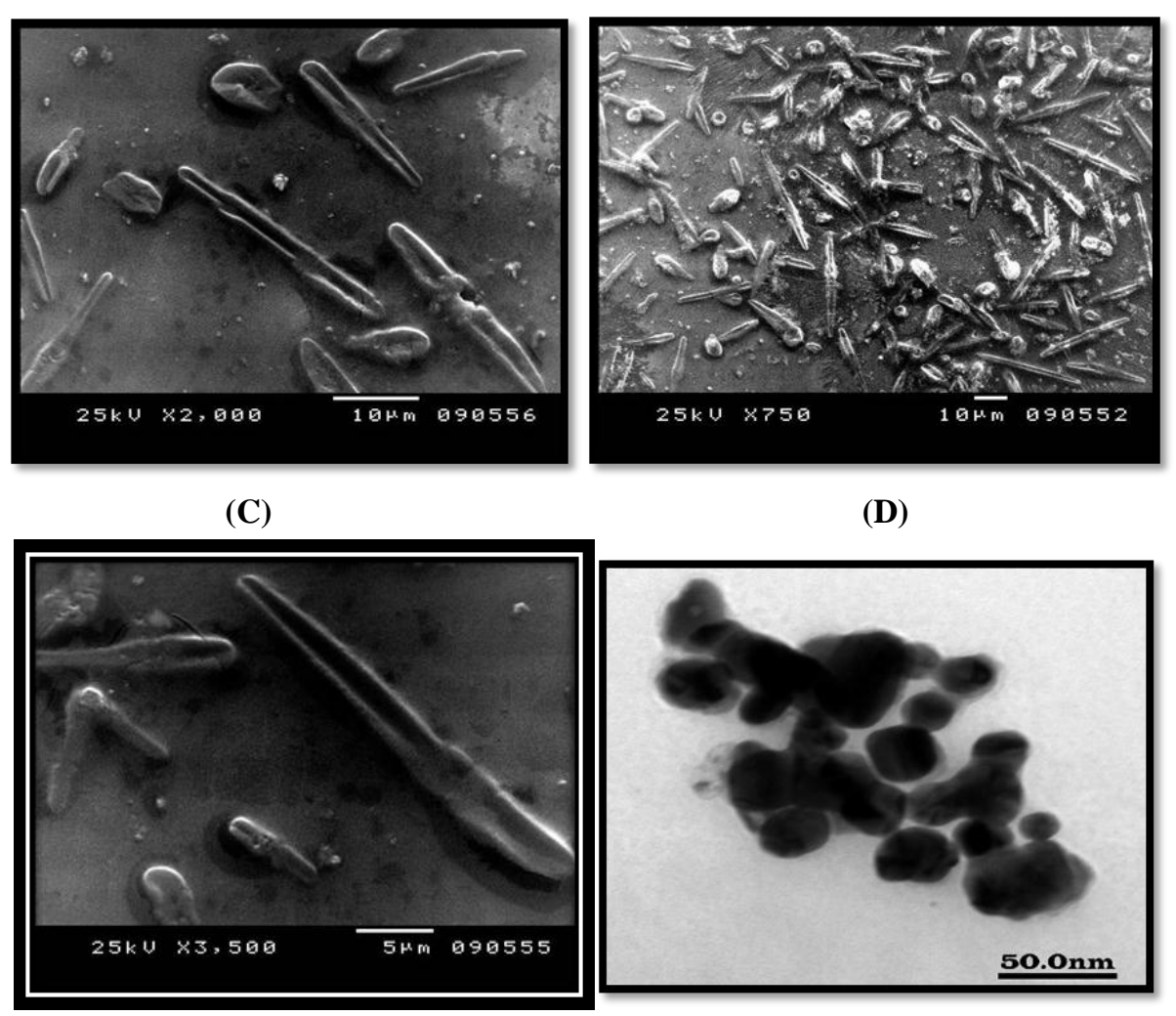

(D)

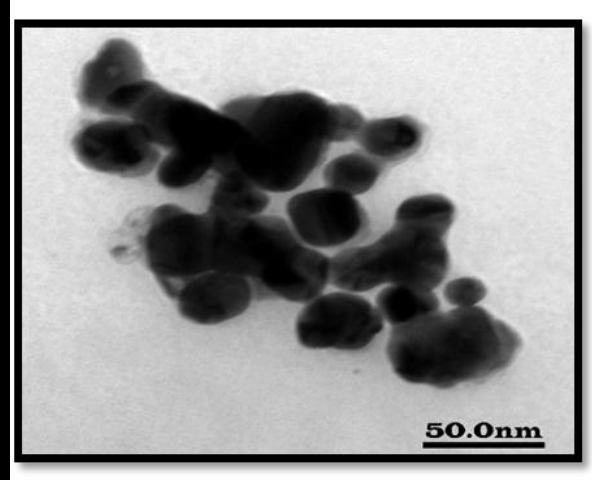

$50.0 \mathrm{~nm}$

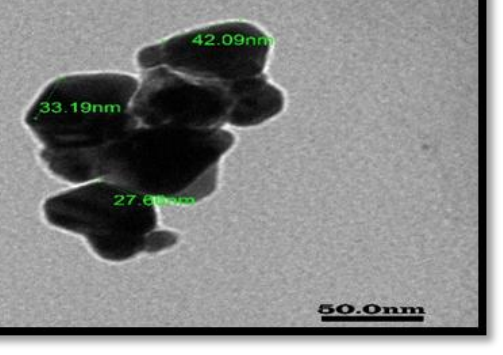

(E)

Figure 3. SEM micrograph (A, B, C) and TEM micrograph (D, E) of synthesized AgNPs 
Table 1. The effect of AgNPs on the mortality of $3^{\text {rd }}$ larval instar of M. domestica by dipping methods after $24 \mathrm{~h}$

\begin{tabular}{ccccc}
\hline Tested Materials & Concentration $\boldsymbol{\mu g} / \mathbf{m l}$ & $\begin{array}{c}\mathbf{2 4 - h} \text { Mortality }(\%) \pm \\
\text { SD }^{\mathrm{a}}\end{array}$ & $\begin{array}{c}\text { LC50 }(\boldsymbol{\mu g} / \mathbf{m l}), \\
(\mathbf{p p m})(\mathbf{L C L} \mathbf{U C L})\end{array}$ & $\mathbf{x}^{2}$ \\
\hline AgNPs by & 60 & $33 \pm 2^{\mathrm{d}}$ & & \\
Dipping method & 40 & $27 \pm 1^{\mathrm{d}}$ & & \\
& 32 & $20 \pm 0.0^{\mathrm{c}}$ & $\mathbf{6 3 . 8}(\mathbf{5 2 . 3 - 8 7 . 9})$ & $\mathbf{6 . 8}(\mathbf{d f}=\mathbf{5})$ \\
& 24 & $7 \pm 0^{\mathrm{a}}$ & \\
& 8 & $7 \pm 1^{\mathrm{a}}$ & \\
$\mathbf{F}(\mathbf{d f = 5})$ & control & $2 \pm 0.57^{\mathrm{b}}$ & \\
\hline
\end{tabular}

-SD standard deviation, LCL lower confidence limits, UCL upper confidence limits, $\chi 2$ chi-squared test * $<<0.05$. Means within column followed by same letter are not significant different $(\mathrm{P}<0.001)$ Duncan's multiple range test

\section{b) Feeding method:}

Larvicidal effect: effects of varying concentration on the mortality of third instar larvae of house fly ( $M$. domestica) was influenced by a beginning fed diet containing AgNPs concentrations (as $\mu \mathrm{g} / \mathrm{ml}$ ). After one day of feeding larvae, the percentage of cumulative mortality significantly increased $(F=13.968 p \leq 0.05$ Sig
$=0.00$ ). The data in table (2) showed that the larval mortality reached the $11 \%-60 \%$ in lowest and highest concentration respectively and the $\mathrm{LC}_{50}=45.5 \mathrm{mg} / \mathrm{ml}$ with confidence limits $(40.1-53.01 \mu \mathrm{g} / \mathrm{ml})$. The mortality rate was found to be increased as the AgNPs increased. Which illustration as Figure (4)

Table 2. The effect of AgNPs on the mortality of $3^{\text {rd }}$ larval instar of $M$. domestica by feeding assay after $24 \mathrm{~h}$

\begin{tabular}{ccccc}
\hline $\begin{array}{c}\text { Tested } \\
\text { Materials }\end{array}$ & $\begin{array}{c}\text { Concentration } \\
\boldsymbol{\mu g} / \mathbf{m l}\end{array}$ & $\begin{array}{c}\mathbf{2 4 - h} \text { Mortality }(\%) \pm \\
\mathbf{S D}^{\mathbf{a}}\end{array}$ & $\begin{array}{c}\text { LC50 }(\boldsymbol{\mu g} / \mathbf{m l}), \\
(\mathbf{p p m})(\mathbf{L C L} \mathbf{U C L})\end{array}$ & $\mathbf{x}^{2}$ \\
\hline $\begin{array}{c}\text { AgNPs by } \\
\text { feeding method }\end{array}$ & 60 & $60 \pm 1 \mathrm{e}$ & & \\
& 40 & $51 \pm 1.5^{\mathrm{d}}$ & & \\
& 32 & $36 \pm 1.5^{\mathrm{c}}$ & $45.5(40.1-53.01)$ & \\
& 24 & $24 \pm 2^{\mathrm{b}}$ & & \\
& 16 & $20 \pm 1^{\mathrm{b}}$ & & \\
& 8 & $11 \pm 1.5^{\mathrm{a}}$ & & \\
$\mathrm{F}(\mathrm{df}=5)$ & control & $0 \pm 0$ & Sig $=0.000$
\end{tabular}

-SD standard deviation, LCL lower confidence limits, UCL upper confidence limits, $\chi 2$ chi-squared test *p<0.05. Means within column followed by same letter are not significant different $(\mathrm{P}<0.001)$ Duncan's multiple range test

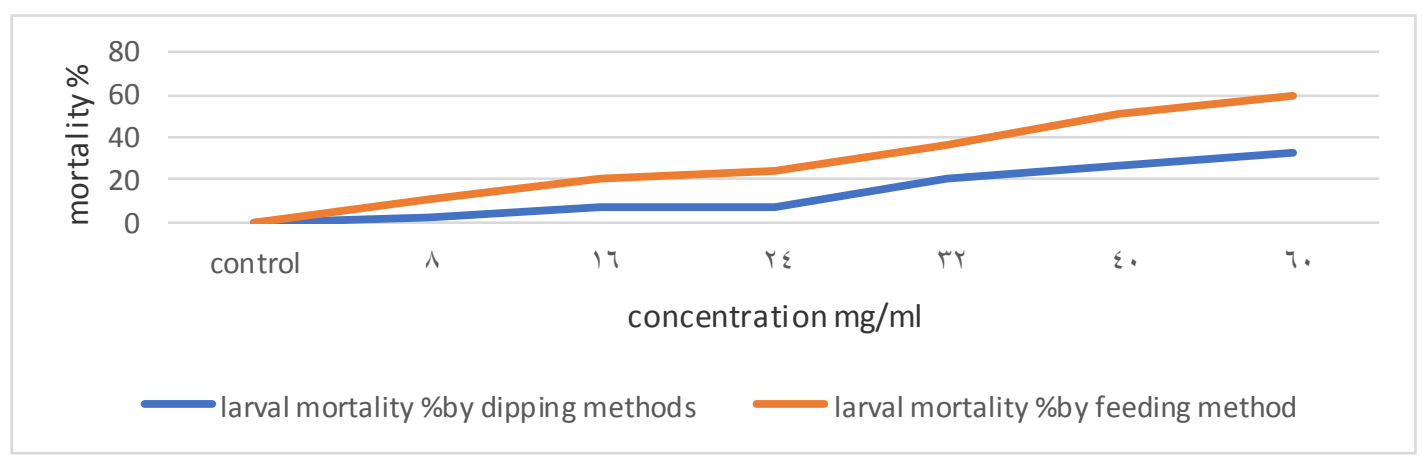

Figure 4. The larval mortality \% of third instar larvae of house fly Musca domestica, resulting from treatment of AgNPs by feeding and dipping methods 


\section{c) Pupicidal activity:}

On the other side, the effects of AgNPs on the pupal stage of the housefly ( $M$. domestica) which treated by feeding assay are mention in the Table (3). The results showed that Ag NPS was highly toxic in the pupal stage the inhibition of pupation (IP\%) reached range (33\% $63 \%$ ) in the highest and smallest concentration respectively and the $\mathrm{LC}_{50}=32 \mu \mathrm{g} / \mathrm{ml}$ with confidence limits (30.559-33.327 $\mu \mathrm{g} / \mathrm{ml})$. So, we can notice that, the toxic effect of Ag NPs was observed in larval mortality especially if we raise the concentration. In the pupal stage, there was a different image, the relationship between concentration and inhibition of pupation was an inverse relation so that the smallest concentration occurs the biggest effect in pupal inhibition. This result was very significant when was analyzed statistically $(\mathrm{F}=3.866 \mathrm{p} \leq 0.05 \mathrm{Sig}=0.001)$. Data in Table (3) illustrated the pupal percentages that were resulted from survived larval treated with AgNPs by feeding method. Furthermore, explained the percentages of both normal and abnormal pupae, and adult inhibition (IR\%). The percentages of adult inhibition ranged between (75$91 \%)(\mathrm{F}=2.895 \leq 0.05 \mathrm{Sig}=0.016)$. Also, Table (4) showed the average weight of pupae that were resulted from treated larvae by AgNPs (feeding method) there was significantly differences between initial weight and the final one in lowest and highest concentrations, while there were no differences in control to be mention. The concentration $8 \mu \mathrm{g} / \mathrm{ml}$ achieved the lowest possible average weight of pupae at the end of the pupal period $(0.122 \mu \mathrm{g})$ while the control was $(0.183 \mu \mathrm{g})$.

\section{Comparison of larvicidal activity of AgNPs by the two methods:}

Figure (4) illustrate comparison between mortality rate when the larvae treated by feeding method or dipping method after $24 \mathrm{~h}$. Control of treatment was found to exhibit no mortality, the larvicidal potential was $60 \%$ when we mixed the AgNPs with food media at the concentration of $60 \mathrm{mg} / \mathrm{ml}$, While it's not more than $33 \%$ at the same concentration. So, we can suggest that larvicidal activity of AgNPs on housefly by feeding method was more efficient than the dipping method.

\section{Morphological abnormalities:}

Treatment of the third instar larvae of $M$. domestica with AgNPs nanoparticles by feeding methods caused noticeable larval, pupae and adult abnormalities. Some deformed larvae were pigmented, sclerotized area among the soft and sclerotization in the tow ends only. And larval-pupal intermediate which had parts of pupal cuticle with persisting last larval skin in their anterior end. Figure (5: a, b, c, d).

Some of the treated larvae were able to pupate, however, the resulting puparia of some individuals showed elongated pupae, some others dwarfed and some of them was swelling, and had abnormal appendages. Figure (6: a, b, c, d, e, f). Finally, most of pupae failed to reach adult however, some emerged adult had various degrees of morphological abnormalities. Some individuals showed a dominance of incomplete adult eclosion of adults. only the head and thorax emerged from the puparium. Meanwhile, some adults were completely free but possessed abnormal appearances such as severely crumpled wings, or partially. Figures (7) a, b, c, d, e, f.

Table 3. Effect of AgNPs on pupation and adult inhibition of house fly, M. domestica resulting from treated larvae feeding assay

\begin{tabular}{|c|c|c|c|c|c|c|c|}
\hline \multirow{2}{*}{$\begin{array}{l}\text { Conc. } \\
\mu \mathrm{g} / \mathrm{ml}\end{array}$} & \multicolumn{3}{|c|}{ Percentage of Pupation } & \multirow{2}{*}{$\begin{array}{c}\mathrm{LC}_{50}(\mu \mathrm{g} / \mathrm{ml}),(\mathrm{ppm}) \\
\left(\mathrm{LCL} \_\mathrm{UCL}\right)\end{array}$} & \multirow[t]{2}{*}{$\mathrm{x}^{2}$} & \multirow{2}{*}{$\begin{array}{c}\text { Adult } \\
\text { inhibition } \\
(\mathrm{IR} \%) \pm \mathrm{SD} \\
\end{array}$} & \multirow[t]{2}{*}{$x^{2}$} \\
\hline & $\begin{array}{c}\text { Produced } \\
\text { pupae } \\
\text { (total) } \%\end{array}$ & $\begin{array}{c}\text { Normal } \\
\text { pupae } \\
\%\end{array}$ & $\begin{array}{c}\text { Abnormal } \\
\text { pupae } \%\end{array}$ & & & & \\
\hline 60 & 40 & 66 & 33 & & & $75 \pm 1.5$ & \\
\hline 40 & 48.8 & 59 & 40.9 & 32 (30.559-33327) & $\begin{array}{c}6.8 \\
(d f=5)\end{array}$ & $71 \pm 2$ & $5.309(\mathrm{df}=5)$ \\
\hline 32 & 64 & 51 & 48.5 & & & $73 \pm 1.5$ & \\
\hline 24 & 75.5 & 50 & 50 & & & $77 \pm 2.6$ & \\
\hline 16 & 80 & 44 & 56 & & & $88 \pm 4.7$ & \\
\hline 8 & 88 & 37.5 & 63 & & & $91 \pm 7.2$ & \\
\hline Control & 100 & 100 & 0 & & & $0 \pm 00$ & \\
\hline$F=3.866$ & & Sig $=0.00$ & & & & $F=2.895$ & Sig $=0.016$ \\
\hline
\end{tabular}


Table 4. the pupal weight resulting from $3^{\text {rd }}$ larval instar of house fly (M. domestica) treated with AgNPs by feeding assay

\begin{tabular}{ccc}
\hline Concentration $\boldsymbol{\mu g} / \mathbf{m l}$ & Initial pupal weight $(\boldsymbol{\mu g})$ & Average pupal weight $(\boldsymbol{\mu g})$ \\
\hline 60 & 0.152 & 0.138 \\
8 & 0.165 & 0.122 \\
Control & 0.185 & 0.183 \\
\hline
\end{tabular}
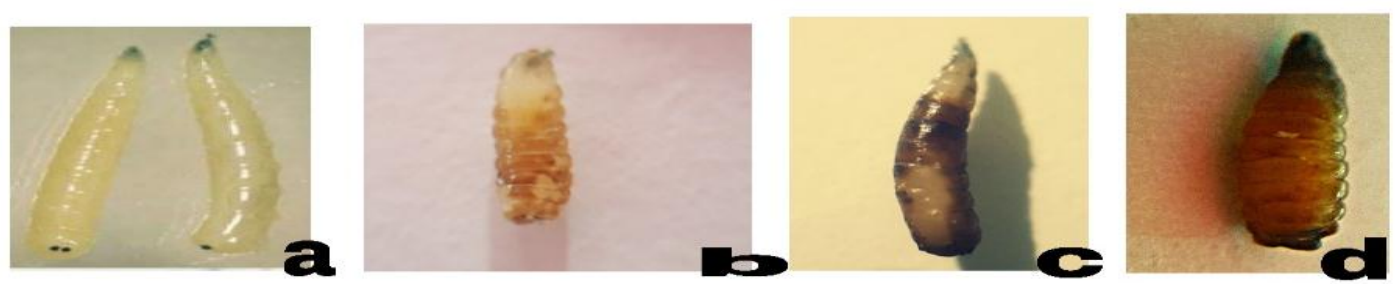

Figure 5. Normal and deformed larvae of housefly M. domestica treated with AgNPs. (a) control larva (b) larva with darkened cuticle (c) larval pupae intermediate (d)
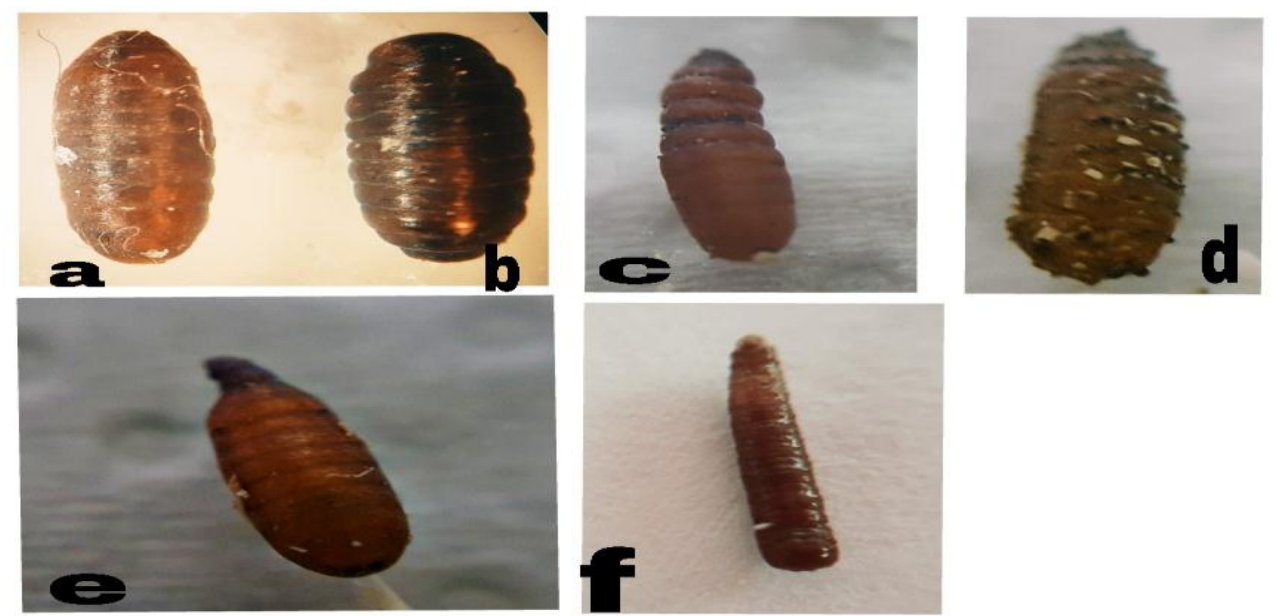

Figure 6. Normal and deformed pupae of housefly M. domestica treated with AgNPs by feeding method. (a) control larvae, (b, c) swelling shape pupae (d, e) abnormalities appendages (f) elongated pupae
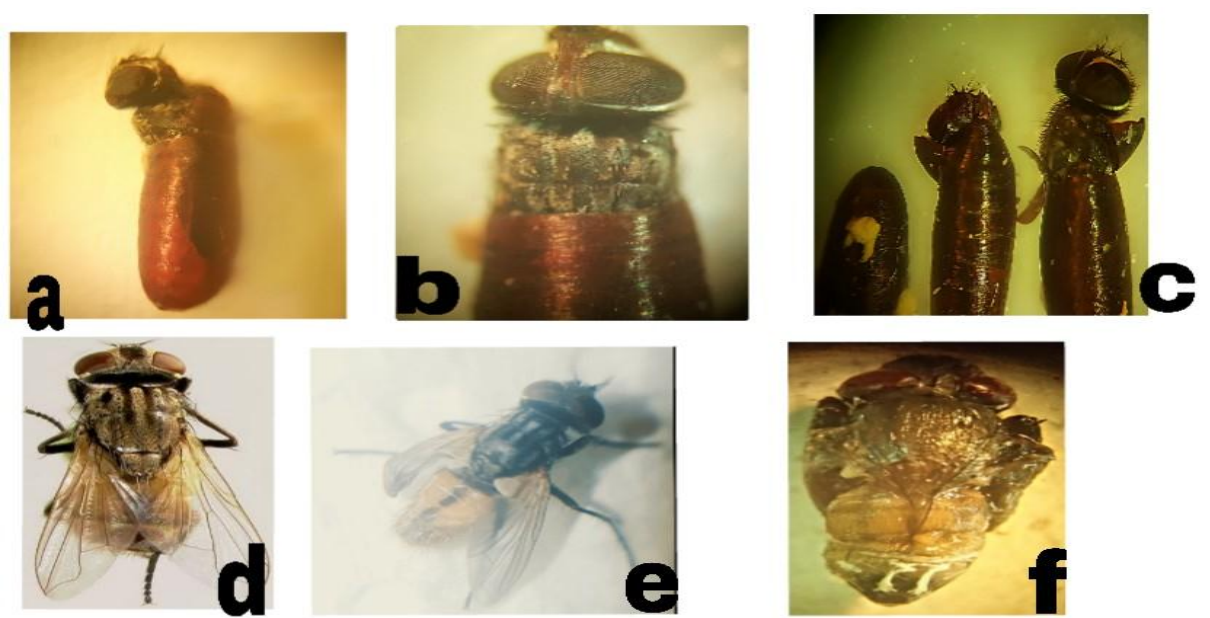

Figure 7. Normal and deformed adult of housefly $M$. domestica treated with AgNPs by feeding method. (a,b,c) incomplete adult eclosion (d) control adult (e,f) adult with crumpled wings 


\section{DISCUSSION}

The present study deals with the chemical synthesis of silver nanoparticles (AgNPs), characterization of these particles and their larvicidal effects against housefly $M$. domestica. The synthesized AgNPs were characterized with UV- visible spectroscopy and scanning, transmission electron microscope. (SEM), (TEM). Generally, UV-VIS spectroscopy can be used to examine the size and shape of AgNPs. (Gnanadesigan et al., 2011; Veerakumar et al., 2013; Velayutham et al., 2013; Soni and Prakash 2014). In this study absorption spectra of Ag nanoparticles formed in the reaction media have an absorbance peak at $413 \mathrm{~nm}$, this agrees with (Guzman et al., 2009; Rashid et al., 2013). Also, the size of nanoparticle determined by the color of the solution when the size of Ag NPs became smaller the colors shift towards red (Mock, 2002), this result was illustrated by UV_VIS image sheet. Preparation of silver nanoparticles by chemical reduction methods generally yields a wide range of sizes and morphologies. (Nikhil, et al., 2001) reported that the wet chemical synthesis of silver nanoparticles produced silver nanorods and nanowires with range size between 15- $18 \mathrm{~nm}$ respectively, (Abdul Zahhir et al., 2012) produced rod Ag nanoparticles in shape and size of $25-80 \mathrm{~nm}$. In the present study, the size and morphological shape of AgNPs were checked by scanning, transmission electron microscope (SEM), (TEM). The size was ranged between $20-50 \mathrm{~nm}$ and the shape seem grain with rough ends. Otherwise, we can describe these nanoparticles shape as polydisperse particles both with initial cubical form and rod-like (in large size). Konenda et al., 2018 record the same result. The larvicidal activity of AgNPs, our results revealed that silver nanoparticles have a moderate toxicity on third instar larvae of Housefly $M$. domestic in the two methods of treatment. (Kamaraj, et al., 2012) determined the feeding deterrent activity of biosynthesized AgNPs against housefly' adults $\left(\mathrm{LD}_{50}=\right.$ $3.64 \mathrm{mg} / \mathrm{mL}$ ). While, Gul, et al., 2016 demonstrate that the synthesized AgNPs effective against $M$. domestica 'adults at lower doses as feeding deterrent, other authors recorded the highest mortality of biosynthesized silver nanoparticles (Marimuthu, et al., 2011) found that the synthesized silver nanoparticles of Mimosa pudica have the highest point of mortality versus the larvae of Anopheles subpictus $\left(\mathrm{LC}_{50}=8.89 \mathrm{ppm}\right)$ and versus the Culex quinquefasciatus larvae $\left(\mathrm{LC}_{50}=9.51 \mathrm{ppm}\right)$. Also, (Salunkhe, et al., 2011) have reported on the larvicidal potential of the AgNPs synthesized using the fungus $C$. lunatus against $A$. aegypti and $A$. stephensi was significant.
Our results revealed that AgNPs concentrations disrupted the normal development of $M$. domestica. These effects resulted in of malformed larvae and pupae, a derangement in the normal developmental rout and a significant decrease in percentage of successful adult emergence specially when we treated these nanoparticles by feeding method.

Until now the mechanism AgNPs insecticidal activity is still unknown. (Rai, et al., 2009) thought the possible mechanism of action could be according to the morphological and structural changes in the bacterial cells. Hence, the larvicidal activity of the AuNPs and AgNPs could be due to the denaturation of proteins containing the sulfur or phosphorous compound like DNA that drove to the denaturation of enzymes and organelles (Sondi and Salopek 2004; Choi, et al., 2008) and the previous results was leads to decreases the cellular membrane permeability and reduction in ATP synthesis. That is finally lead up to the loss of the cellular function and cell death (Sap-Iam, et al., 2010). the insecticidal activity of synthesized silver nanoparticles by Sargassum muticum extract antagonistic towards Ergolis merione detect eminent changes in the protein profile of hemolymph, morphology of hemocytes and the mid-gut was inclusions lost such as lumen, basement membrane, fat body and gastric caeca (Moorthi, et al., 2015). Finally, the use of nanomaterials in agriculture is still at a rudimentary stage (Stadler, et al., 2010) but we think in this present study can open the opportunities to other researchers to investigate another effect of these nanoparticles by the difference in pest species, a dose of the treatment, methodology of research, varietal and commodity variations, and laboratory and environmental differences.

\section{REFERENCES}

Abbott, W. S. 1925. A method of computing the effectiveness of an insecticide. J. Econ. Entomol., 18(2): 265 - 267.

Abdul Zahir, A., A. Bagavan, C. Kamaraj, G. Elango, and A. Abdul Rahuman. 2012. Efficacy of plant-mediated synthesized silver nanoparticles against Sitophilus oryzae. J. Biopest, 5: 95 - 102.

Arbain, R., M. Othman, and S. Palaniandy. 2011. Preparation of iron oxide nanoparticles by mechanical milling. Miner Eng. 24: $1-9$.

Begum, N., S. Mondal, S. Basu, R. Laskar, and D. Mandal. 2009. Biogenic synthesis of $\mathrm{Au}$ and $\mathrm{Ag}$ nanoparticles using aqueous solutions of black tea leaf extracts. Colloids Surf B Biointerfaces. 71(1): 113 - 118.

Bordes P., E. Pollet, L. Avérous. 2009. Nano-biocomposites: biodegradable polyester/nanoclay systems. Progress in Polymer Science.34(2):125-155. 
Chinnamuthu, C. and P. Murugesa-Boopathi. 2009. Nanotechnology and Agroecosystem. Madras Agricultural Journal. 96: $17-31$.

Choi, O., K. Deng, N. Kim, L. Rose, R. Surampalli, and Z. Hu. 2008. The inhibitory effects of silver nanoparticles, silver ions and silver chloride colloids on microbial growth. Water Resources 42: 3066 - 3074.

Finney, D. J. 1971. Probit Analysis, 3rd ed. Cambridge University Press, Cambridge (ISBN 052108041X. OCLC 174198382).

Fotedar, R. 2001. Vector potential of houseflies, Musca domestica, in the transmission of Vibrio cholerae in India. Acta Trop. 78: $31-34$.

Gul, S.,M. Ismail, M. Khan, S. Khan, A. Asiri, I. Rahman, M. Khan, and A. Kamboh. 2016. Novel synthesis of silver nanoparticles using melon aqueous extract and evaluation of their feeding deterrent activity against housefly Musca domestica. Asian Pac. J. Trop. Dis. 6(4): 311 - 316.

Gnanadesigan, M., M. Anand, S. Ravikumar, M. Maruthupandy, V. Vijayakumar, S. Selvam, M. Dhineshkumar and A. Kumaraguru. 2011. Biosynthesis of silver nanoparticles by using mangrove plant extract and their potential mosquito larvicidal property. Asian Pacific J. Trop. Med. 4(10): $799-803$.

Guzman, G., J. Dille, and S. Godet. 2009. Synthesis of silver nanoparticles by chemical reduction method and their antibacterial activity. Inter. J. of Chem. and Biomolecular Engine. 2(3): 104 - 111.

Hinkle, N. C. 2002. Poultry pest management (Arthropods) In: D. Pimentel (ed.), Encyclopedia of Pest Management. Marcel Dekker, Inc., New York, Pp. 657 - 660.

Kamaraj, C., G. Rajakumar, A. Rahuman, K. Velayutham, A. Bagavan, A. Zahir, and G. Elango. 2011. Feeding deterrent activity of synthesized silver nanoparticles using Manilkara zapota leaf extract against the house fly, Musca domestica (Diptera: Muscidae). Parasitol. Res. doi:10.1007/s00436-011-2689-5.

Khot, L., S. Sankaran, J. Maja, R. Ehsani and E. Schuster. 2012. Applications of nanomaterials in agricultural production and crop protection: A review. Crop Protection. 35: $64-70$.

Konendan, K., B. Chanderamohan, M. Govindarajan, A. Jebanesam, S. Kamalakannan, S. Vincent and G. Benelli. 2018. Orchids as Sources of Novel Nanoinsecticides? Efficacy of Bacillus sphaericus and Zeuxine gracilisFabricated Silver Nanoparticles Against Dengue, Malaria and Filariasis Mosquito Vectors. J. Cluster Science, 29: $345-357$.

Malik, A., N. Singh and S. Satya.2007. Housefly, Musca domestica: A review of control strategies for a challenging pest. J. Environ. Sci. Health. 42: 453 - 469.

Margulis-Goshen, K. and S. Magdassi. 2013. Nanotechnology: An advanced approach to the development of potent insecticides. In: Ishaaya I, Palli S, Horowitz A (eds) Advanced Technologies for Managing Insect Pests. Springer, Dordrecht, pp. 295-314.
Marimuthu, S., A. Rahuman, G. Rajakumar, T. Santhoshkumar, A. Kirthi, C. Jayaseelan, A. Bagavan, A. Zahir, G. Elango and C.Kamaraj. 2011. Evaluation of green synthesized silver nanoparticles against parasites. Parasitol. Res. 108(6): 1541 - 1549.

Moorthi, P., C. Balasubramanian and S. Mohan. 2015. An improved insecticidal activity of silver nanoparticle synthesized by using Sargassum muticum. Appl. Biochem. Biotechnol. 175(1): 135 - 140.

Mock, J., M. Barbic, D. Smith, D. Shultz and S. Shultz. 2002. Shape effect in plasmon resonance of individual colloidal silver nanoparticles. J. of Chemistry and Physics. 116: $6755-6759$.

Navaladian, S., B. Viswanathan, R. Viswanath and T. Varadarajan. 2007. Thermal decomposition as route for silver nanoparticles. Nanoscale Res. Lett. 2: $44-48$.

Nikhil, R., J. Gearheart and C. Murphy. 2001. Wet chemical synthesis of silver nanorods and nanowires of controllable aspect ratio. Chem. Comm. 617-618.

Pavela, R. (2008) Insecticidal properties of several essential oils on the housefly, M. domestica L. Phytother. Res. .22: $274-278$.

Rai, M., A. Yadav and A. Gade. 2009. Silver nanoparticles as a new generation of microbials. Biotechnol. Adv. 27: $76-$ 83.

Rashid, M., H. Bhuiyan and E. Quayum. 2013. Synthesis of Silver Nano Particles (Ag-NPs) and their uses for Quantitative Analysis of Vitamin C Tablets. Dhaka Univ. J. Pharma. Sci.12(1): 29 - 33.

Salunkhe, R., V. Patil, D. Patil and K. Salunke. 2011. Larvicidal potential of silver nanoparticles synthesized using fungus Cochliobolus lunatus against Aedes aegypti (Linnaeus, 1762) and Anopheles stephensi Liston (Diptera; Culicidae). J. Parasitol Res. 109:823-831.

Sap-Iam, N., C. Homklinchan, R. Larpudomlert, W. Warisnoicharoen, A. Sereemaspun and S. Dubas. 2010. UV irradiation induced silver nanoparticles as mosquito larvicides. J. Appl. Sci. 10 (23): 3132 - 3136.

Singh, P. and E. Jerram. 1976. Rearing housefly larvae in polyethene bags. New Zealand J. of Zoology. 3: 57 - 58.

Sinthusiri, J. and M. Soonwera. 2010. Effect of herbal essential oils against larvae, pupae and adults of house fly (Musca domestica: Diptera). Proceedings of 16th Asian Agricultural Symposium and 1st Int. Symposium on Agricultural Technology, August, 2010, Bangkok, Thailand, pp: 639 - 642.

Sondi, I. and S. Salopek. 2004. Silver nanoparticles as antimicrobial agents: a case study on E. coli as a model Gram-negative bacterium. J Colloid Interface Sci. 275: $177-182$.

Soni, N. and S. Prakash. 2014. Green nanoparticles for mosquito control. The Scientific World J. Article. http:// dx.doi.org/10.1155/2014/496362.

Sreeram, K., M. Nidin, and B. Nair. 2008. Microwave assisted template synthesis of silver nanoparticles. Bull. Mater. Sci. 31(7): $937-942$. 
Srinivasan, R., P. Jambulingam, K. Gunasekaran and P. Boopathidoss. 2008. Tolerance of housefly, M. domestica (Diptera: Muscidae) to dichlorovos, an insecticide used for fly controlling the tsunami hit coastal villages of southern India. Acta Trop. 105: 187 - 190.

Stadler, T., M. Butelerb and D. Weaver. 2010. Novel use of nanostructured alumina as an insecticide. Pest Management Science. 66: 577 - 579.

Starowicz, M., B. Stypula and J. Banas. 2006. Electrochemical synthesis of silver nanoparticles. Electrochem. Comm. 8 (2): $227-230$.

Steenberg, T. and J. Jespersen. 2002. Control of houseflies and filth flies In: D. Pimentel (ed.), Encyclopedia of Pest Management. Marcel Dekker, Inc., New York, Pp. 144147.

Tahmasebi, P., F. Javadpour and M. Sahimi. 2015. Three dimensional stochastic characterization of shale SEM images. transport in Porous Media 110(3): 521-531.

Veerakumar, K., M. Govindarajan, and M. Rajeswary. 2013. Green synthesis of silver nanoparticles using, Sida acuta (Malvaceae) leaf extract against Culex quinquefasciatus,
Aedes aegypti and Anopheles stephensi (Diptera: Culicidae). Parasitol. Res. 112 (12): 4073 - 4085.

Velayutham, K., A. Rahuman, G. Rajakumar, S. Roopan, G. Elango, C.Kamaraj, S. Marimuthu, T. Santhoshkumar, M. Iyappan and C. Siva. 2013. Larvicidal activity of green synthesized silver nanoparticles using bark aqueous extract of Ficus racemosa against Culex quinquefasciatus and Culex gelidus. Asian Pacific J. Trop. Med. 6 (2): 95 101.

Wildenberg, and V. D. Willems. 2005. Roadmap report on nanoparticles. W\&W Espana S.1. Barcelona, Spain.

Winpisinger, K., A. Ferketich, R. Berry and M. Moeschberger. 2005. Spread of Musca domestica (Diptera: Muscidae) from two caged layer facilities to neighboring residence in rural Ohio. J. Medical Entomology. 42: 732-738.

Wright, J.W. 1971. The WHO programme for the evaluation and testing of new insecticides. Bull. World Health Organ. 44: 9 - 22

Yeo, S., H. Lee and S. Jeong. 2003. Preparation of nanocomposite fibers for permanent antibacterial effect. J. Mater. Sci. 38: 2143 - 2147.

\title{
الملخص العربي
}

\section{Musca domestica (Diptera: Muscidae)}

\author{
مديحة محمد عبد الحميد ، إجلال محمود هلال و فدوى طه محمدين \\ التركيز القاتل ل .0\% من اليرقات 0,0 0ـ ملجرام/مل.

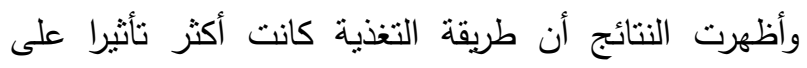 \\ معدل تثبيط العذارى وظهور الحشرات الكاملة وتم ملاحظة \\ وتسجيل هذا التأثير في شكل تغيرات مورفولوجية في كل من \\ اليرقات والعذارى كما إن بعض الحشرات الكاملة لم تستطع \\ التخلص من غلافها العذري والبعض الأخر نجح في الخروج \\ ولكن مع أجنحة مشوهة أفضت إلى الموت. وقد أوصت \\ الدراسة أن إستعمال جسيمات الفضة المنتاهية الصغر خهنه \\ مع بيئة تغذية اليرقات يؤدي الى ارتفاع معدل تثبيط العذراي

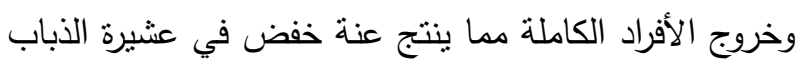 \\ اللاحقة للمعاملة. \\ في هذا البحث نم تصنيع جسيمات الفضة المتتاهية \\ الصغر من خلال الطرق الكميائية وتوصيفها عن طريق \\ أجهزة التحليل الطيفي للأشعة فوق البنفسجية وتم مسح \\ العينات بواسطة الميكرسكوب الإلكتروني حيث تبين أن حجم \\ الجسيمات يتراوح ما بين • ب - .0 نانوميتر وشكلها حبيبي \\ ذو حواف خشنة. ونم إختبار النشاط الإبادى لهذه الجسيمات \\ على يرقات العمر الثالث للذبابة المنزلية بواسطة طريقتين : \\ الأولى عن طريق خلط الجسيمات مع البيئة الغذئية بتركيزات

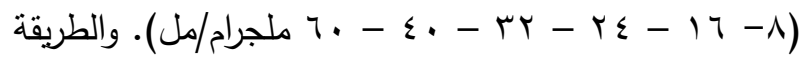 \\ الثانية عن طريق الغمر وتم حساب نسبة الموت بعد ؟ ب \\ ساعة من المعاملة. أوضحت النتائج أن كلا من المعاملتين \\ أعطت تأثيرا معتدلا في النشاط الإبادي لليرقات وكانت قيمة
}

